Article

\title{
The Effect of Growth Activators and Plant Growth-Promoting Rhizobacteria (PGPR) on the Soil Properties, Root Yield, and Technological Quality of Sugar Beet
}

\author{
Arkadiusz Artyszak *(i) and Dariusz Gozdowski \\ Institute of Agriculture, Warsaw University of Life Sciences-SGGW, Nowoursynowska 159, 02-776 Warsaw, \\ Poland; dariusz_gozdowski@sggw.edu.pl \\ * Correspondence: arkadiusz_artyszak@sggw.edu.pl; Tel.: +48-22-593-2702
}

Received: 27 July 2020; Accepted: 23 August 2020; Published: 26 August 2020

check for updates

\begin{abstract}
The strategy "from farm to fork" assumes a reduction in the usage of fertilizers and plant protection products in EU agriculture. The aim of this study, conducted over the years 2017-2019 in several locations in Poland, is to evaluate the application of growth activators with and without plant growth-promoting rhizobacteria to reduce mineral nitrogen fertilization without negative effects on the root yield. We studied the effect of these activators on selected soil properties. The experimental treatments included the application of the growth activators Penergetic $(K+P)$ and Azoter, which contains the bacteria Azotobacter chroococcum, Azospirillum brasilense, and Bacillus megaterium, before sowing or during vegetation. The nitrogen rates were reduced by $30 \%$ in comparison to full nitrogen mineral fertilization (control treatment). In selected experiments, the application of Penergetic and Penergetic with Azoter caused a higher content of nitrate nitrogen $\left(\mathrm{N}-\mathrm{NO}_{3}\right)$ and ammonium nitrogen $\left(\mathrm{N}_{-} \mathrm{NH}_{4}\right)$ after the sugar beet harvest as well as higher contents of mineral nitrogen (Nmin), $\mathrm{P}, \mathrm{K}$, and $\mathrm{Mg}$ in the soil in comparison to the treatment with the full dose of mineral nitrogen fertilization. The obtained results proved that it was possible to reduce the mineral application of nitrogen by $30 \%$ without a decrease in the biological and pure sugar yield, and even with an increase in the sugar yield caused by the application of the growth activators Penergetic $(\mathrm{K}+\mathrm{P})$ and Azoter.
\end{abstract}

Keywords: growth activator; nitrogen; plant growth-promoting rhizobacteria; sugar beet

\section{Introduction}

An expected $50 \%$ growth in the global population during the 21st century demands advanced technologies and low-input crop management, including precision delivery of nutrients at certain growth stages of crops [1].

In the crop production of sugar beet, new and effective methods of increasing sugar yields have been introduced. One of the innovations is the foliar application of silicon [2-9]. To protect the environment, efforts are typically made to limit the doses of mineral nitrogen. An innovative method is the application of the growth activators Penergetic P and K. A beneficial effect of the application of Penergetic-P for yield was proved in potatoes [10], sugar beet [11], snap-beans [12], and coffee [13]. A positive effect of Penergetic-K on grain yield and its quality was observed in organic wheat production [14] and soybeans [15]. A positive effect of the preparation on the seed germination energy and biometric traits of vegetables was also observed [16] as well for seedlings of winter wheat [17]. Nascente and Cobucci [18] observed positive effects of Penergetic-K and P application on the seed yield of common beans. 
Various groups of bacteria that are able to stimulate plant growth by a mechanism(s) of action are referred to as plant growth-promoting rhizobacteria (PGPR). They affect plant growth and development directly or indirectly either by releasing plant growth regulators (PGRs) or other biologically active substances. This causes an increase in the content of available nutrients, which increase nutrient uptake and reduces the negative effects of pathogenic microorganisms on plants [19]. PGPRs have various types of effects, such as an increase in root growth and nutrient uptake, the stimulation of plant hormones, inhibition of the activity of plant pathogens, improvement of the soil structure, and mineralization of organic pollutants [20].

Biofertilizers increase nutrient availability and crop health without negative environmental effects [21]. Bacterial-based biofertilizers and the plant probiotics market is growing all around the world due to the need for sustainable crop production [22]. One example of the commercial application of Azospirillum sp. inoculants is the use in approximately 3.5 million ha in South America [23]. In the near future, plant growth-promoting bacteria (PGPB) will begin to replace the use of fertilizers and pesticides in agriculture [24]. Rhizospheric bacteria and fungi in the form of biofertilizers and biopesticides allow for reduced application of synthetic chemicals in crop production [25]. Plant growth-promoting rhizobacteria with probiotic potential can improve plant health and yield without negative environmental effects [26].

The aim of the study was to evaluate the effect of growth activators with and without plant growth-promoting rhizobacteria on sugar beet to avoid the negative effects of $\mathrm{N}$ fertilization on sugar yield and selected soil properties.

\section{Materials and Methods}

In the years 2017-2019, we conducted seven field experiments with sugar beet: three in 2017 (Sahryń, Pagów, and Stegienka), one in 2018 (Sahryń), and three in 2019 (Sahryń, Pagów, and Kępina) (Figure 1). The experiments were conducted on the following soils: Sahryń-Calcic Chernozem; and Pagów, Kępina, and Stegienka—Albic Podzols [27].

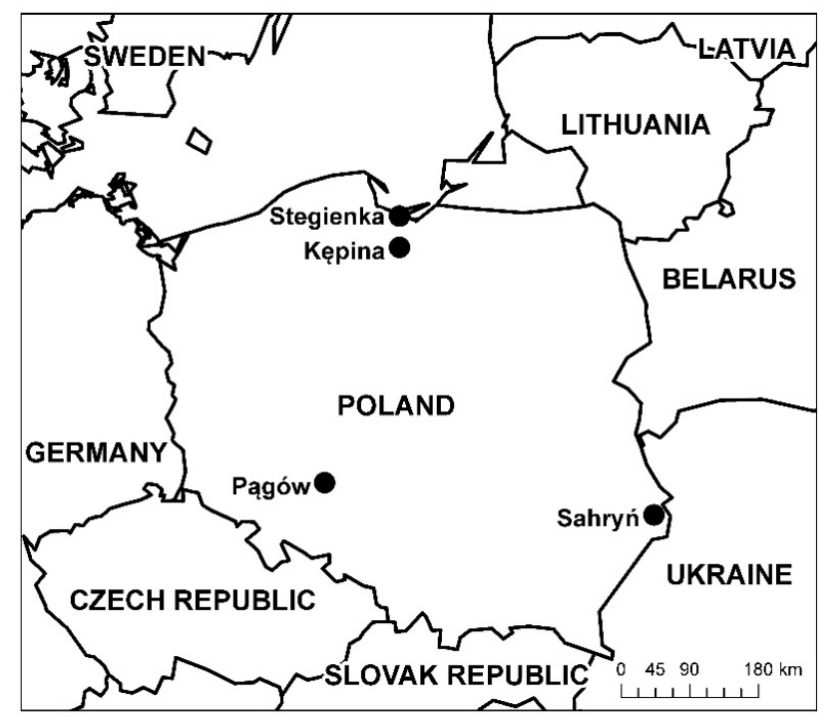

Figure 1. Location of the field experiments.

Soil samples were collected at two soil depths $(0-30$ and 30-60 cm) two times: immediately after harvesting the forecrop and after harvesting sugar beet. At the District Chemical and Agricultural Stations in Warszawa-Wesoła, Opole, and Gdańsk, the soil parameters were evaluated $\left(\mathrm{pH}_{\mathrm{KCl}}\right)$ potentiometrically in $1 \mathrm{M} \mathrm{KCl}$ [28], for the content of soil organic carbon (SOC) [29], nitrate nitrogen $\left(\mathrm{N}-\mathrm{NO}_{3}\right)$ and ammonium nitrogen $\left(\mathrm{NH}_{4}\right)$ [30], available phosphorus (P) [31], available potassium (K) [32], available 
magnesium (Mg) [33], available boron (B) [34], available copper (Cu) [35], available iron (Fe) [36], available manganese (Mn) [37], and available zinc ( $\mathrm{Zn})$ [38].

The $\mathrm{pH}$ of the soil before the experiments was established as neutral or alkaline, except for Kępina in 2019 (in the layer from 0-30 cm) (Table 1). The pH of the SOC was in the range of 1.15-3.54 $(0-30 \mathrm{~cm})$ and $0.95 \%-2.97 \%(30-60 \mathrm{~cm})$. For $0-30$ and $30-60 \mathrm{~cm}$, respectively, the $\mathrm{N}-\mathrm{NO}_{3}$ was at $5.7-81.5$ and

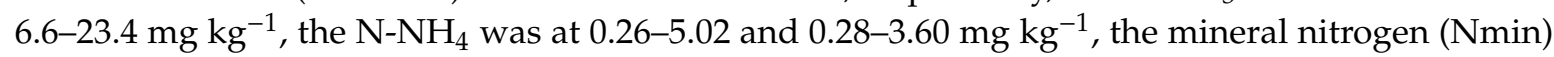
was at 23-337 and 32-105 $\mathrm{kg} \mathrm{ha}^{-1}$, the $\mathrm{P}$ was at $46-145$ and $27-155 \mathrm{mg} \mathrm{kg}^{-1}$, the $\mathrm{K}$ was at $62-254$ and $47-242 \mathrm{mg} \mathrm{kg}^{-1}$, and the $\mathrm{Mg}$ was at $69-153$ and 70-137 $\mathrm{mg} \mathrm{kg}^{-1}$. For 0-30 and 30-60 cm, respectively, the content of available micronutrients was $\left(\mathrm{mg} \mathrm{kg}^{-1}\right)$ : B-2.10-5.57 and 1.49-4.54, $\mathrm{Cu}-2.70-14.2$ and 2.6-13.1; Fe-490-2573 and 520-2814, Mn-142-391 and 93-387, and $\mathrm{Zn}-5.9-26.4$ and 4.8-25.8.

Table 1. Soil conditions before establishing the experiment with sugar beet (2016-2018).

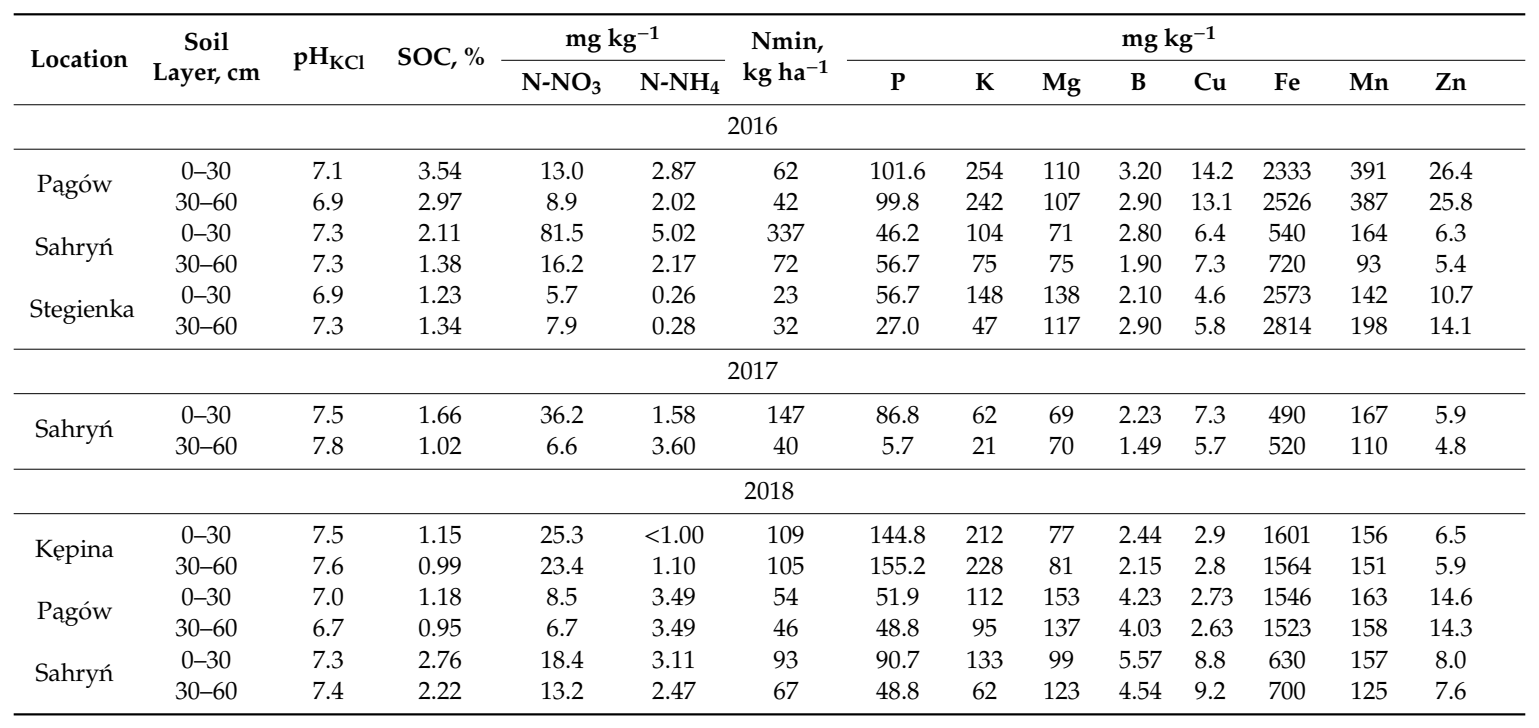

The amount of rainfall during the growing season (April-October) in the year 2017 was $443-615 \mathrm{~mm}$, in 2018-466 mm, and in 2019, from 364 to $426 \mathrm{~mm}$ (Table 2). During the period of the highest demand of sugar beet for water (June-August), the optimal value of the k-factor was found only in 2017 in July and August 2019 in Pagów and in June 2019 in Kępina. Sugar beet was grown in Sahryń after winter rapeseed, and in other locations after winter wheat. The characteristics of the technology used in the experiments are presented in Table 3.

Table 2. Weather conditions during the growing season of sugar beet (2017-2019).

\begin{tabular}{ccccc}
\hline Location & Month & Precipitation, $\mathbf{~ m m}$ & Average Temperature, ${ }^{\circ} \mathbf{C}$ & Hydrotermical Coefficient, $\mathbf{k}^{\circ}$ \\
\hline \multirow{6}{*}{ Sahryń } & 2017 & & \\
& April & 36 & 8.6 & 1.40 \\
& May & 45 & 13.5 & 1.08 \\
& June & 34 & 18.2 & 0.62 \\
& July & 95 & 18.9 & 1.62 \\
& August & 12 & 20.8 & 0.19 \\
& September & 118 & 14.5 & 2.71 \\
& October & 103 & 10.1 & 3.29 \\
& Sum & $\mathbf{4 4 3}$ & - & - \\
\hline
\end{tabular}


Table 2. Cont.

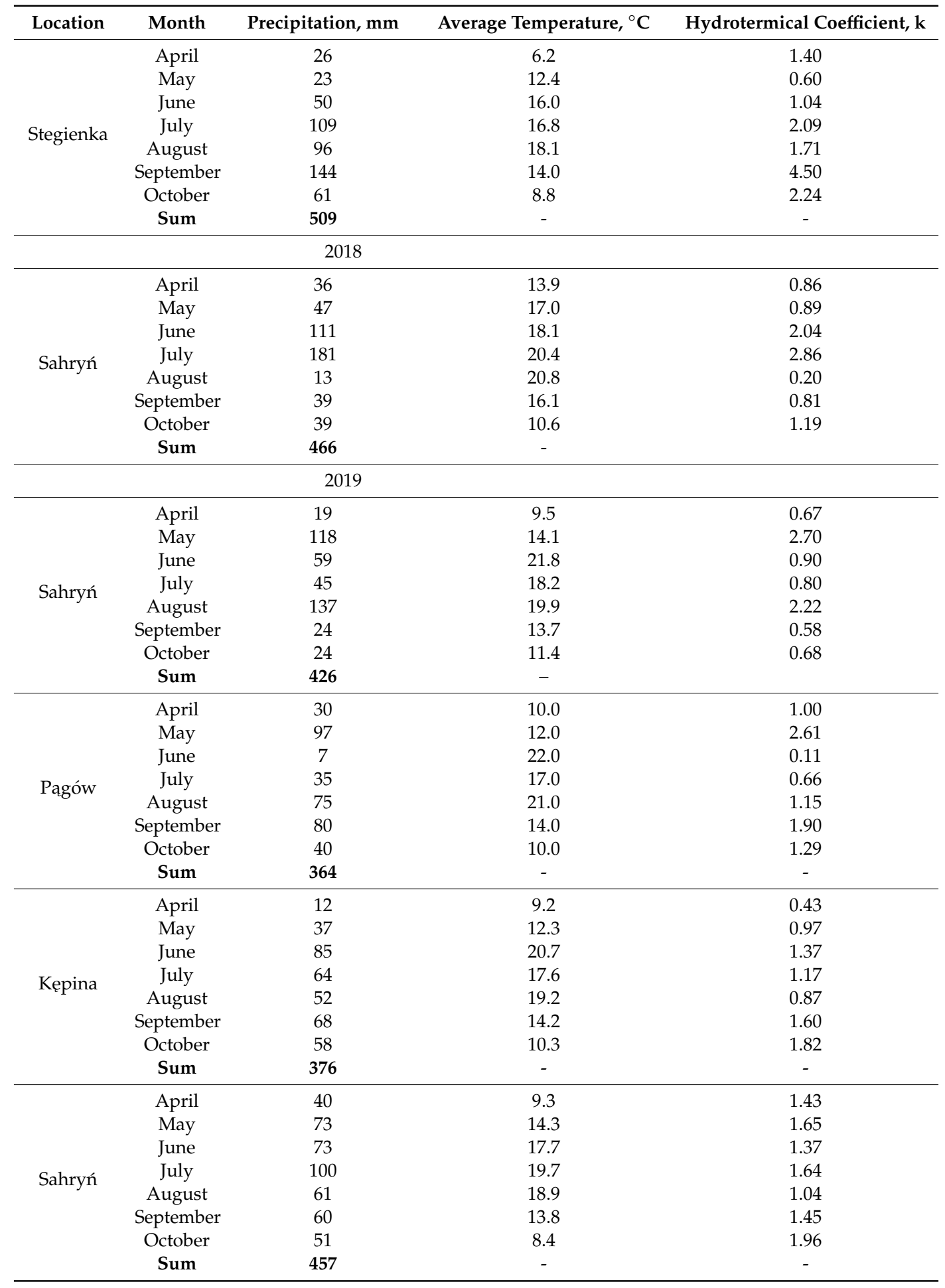


Table 2. Cont.

\begin{tabular}{ccccc}
\hline Location & Month & Precipitation, $\mathbf{~ m m}$ & Average Temperature, ${ }^{\circ} \mathbf{C}$ & Hydrotermical Coefficient, $\mathbf{k}$ \\
\hline Location & & \multicolumn{2}{c}{ Average from multiyear ${ }^{*}$} \\
& Month & Precipitation, mm & Average Temperature, ${ }^{\circ} \mathrm{C}$ & Hydrotermical Coefficient, $\mathrm{k}$ \\
\hline & April & 37 & 9.5 & 1.30 \\
& May & 64 & 14.4 & 1.43 \\
Pagów & June & 64 & 17.9 & 1.19 \\
& July & 89 & 19.7 & 1.46 \\
& August & 57 & 19.0 & 0.97 \\
& September & 59 & 13.7 & 1.44 \\
& October & 49 & 9.0 & 1.76 \\
& Sum & $\mathbf{4 1 8}$ & - & - \\
\hline \multirow{5}{*}{ Stegienka/ } & April & 28 & 7.8 & 1.20 \\
Kepina & July & 49 & 12.9 & 1.23 \\
& August & 61 & 16.0 & 1.27 \\
& September & 71 & 18.5 & 1.26 \\
& October & 58 & 18.2 & 1.40 \\
& Sum & 53 & 13.8 & 1.99 \\
\hline
\end{tabular}

* Precipitation: Sahryń (1991-2019), Pagów (1998-2019), Stegienka and Kępina (2001-2019). Temperature: Sahryń (2002-2019), Pagów, Stegienka and Kępina (2001-2019). Source: own study based on data from Institute IMGW-PIB, "Pagro" farm, Strzyżów Sugar Factory.

In the experiments during autumn, we applied (depending on location) Polifoska 6 fertilizer ( $6 \% \mathrm{~N}$ in ammonium form, $8.7 \% \mathrm{P}$ as mono and diammonium phosphate, $24.9 \% \mathrm{~K}$ as potassium chloride, and $2.8 \% \mathrm{~S}$ as sulphate), potassium chloride $(49.8 \% \mathrm{~K}$ as potassium chloride), and Korn-Kali-potassium chloride with the addition of magnesium salt $(33.2 \% \mathrm{~K}, 3.6 \% \mathrm{Mg}, 3 \% \mathrm{Na}$, and $5 \% \mathrm{~S})$. In spring, before sowing, we applied Saletrzak Standard 27-ammonium nitrate with the addition of dolomite flour containing calcium and magnesium $(13.5 \% \mathrm{~N}$ in the ammonium form and $13.5 \% \mathrm{~N}$ in the nitrate form, $1.4 \% \mathrm{Ca}$, and $2.4 \% \mathrm{Mg}$ ) or ammonium sulphate $32(16 \% \mathrm{~N}$ in the ammonium form and $16 \% \mathrm{~N}$ in the nitrate form).

During the growing season in the experiment, at the six-leaf stage of sugar beet (Biologische Bundesanstalt, Bundessortenamt und Chemical Industry growth scale (BBCH 16)) and 14 days later, foliar nutrition was conducted with micronutrient fertilizers containing boron $\left(2 \times 300 \mathrm{~g} \mathrm{ha}^{-1} \mathrm{~B}\right)$. Protection against weeds, diseases, and pests was performed in accordance with the recommendations of the Institute of Plant Protection-National Research Institute in Poznań.

In the experiment, three treatments were applied:

0- Control (full nitrogen fertilization dose depending on the location-from 112 to $175 \mathrm{~kg} \mathrm{ha}^{-1} \mathrm{~N}$ );

1 - Dose of mineral nitrogen lower by $30 \%$ in comparison to the full dose before sowing and during vegetation-from 78 to $123 \mathrm{~kg} \mathrm{ha}^{-1} \mathrm{~N}$; Penergetic-K $\left(400 \mathrm{~g} \mathrm{ha}^{-1}\right)$ on the straw of the forecrop before it was mixed with the soil; Penergetic-K $\left(400 \mathrm{~g} \mathrm{ha}^{-1}\right)$ with the first herbicide spray; Penergetic-P $\left(300 \mathrm{~g} \mathrm{ha}^{-1}\right)$ with a second herbicide spray in spring; and Penergetic-P $\left(300 \mathrm{~g} \mathrm{ha}^{-1}\right)$ at the six-leaf stage of sugar beet (Biologische Bundesanstalt, Bundessortenamt und Chemical Industry growth scale (BBCH 16));

2- Dose of mineral nitrogen lower by $30 \%$ in comparison to the full dose before sowing and during vegetation-from 78 to $123 \mathrm{~kg} \mathrm{ha}^{-1} \mathrm{~N}$; Penergetic-K $\left(400 \mathrm{~g} \mathrm{ha}^{-1}\right)+$ Azoter $\left(10 \mathrm{dm}^{3} \mathrm{ha}^{-1}\right)$ on the straw of the forecrop before it is mixed with the soil; Penergetic-K $\left(400 \mathrm{~g} \mathrm{ha}^{-1}\right)+$ Azoter $(10$ $\left.\mathrm{dm}^{3} \mathrm{ha}^{-1}\right)$ in spring with the first herbicide spraying; Penergetic-P $\left(300 \mathrm{~g} \mathrm{ha}^{-1}\right)$ with the second herbicide spray; and Penergetic-P (300 $\left.\mathrm{g} \mathrm{dm}^{3} \mathrm{ha}^{-1}\right)$ at the six-leaf stage of sugar beet (BBCH 16). 
Table 3. Characteristics of sugar beet production technology in the experiment (2017-2019).

\begin{tabular}{|c|c|c|c|c|c|c|c|}
\hline Location & Forecrop & $\begin{array}{l}\text { Straw Yield of } \\
\text { Forecrop, } \mathrm{t} \mathrm{ha}^{-1}\end{array}$ & $\begin{array}{l}\text { Cultivar of Sugar } \\
\text { Beet }\end{array}$ & Mineral Fertlization, $\mathrm{kg} \mathrm{ha}^{-1}$ & Sowing Date & Harvest Date & $\begin{array}{l}\text { Length of Vegetation } \\
\text { Period (Days) }\end{array}$ \\
\hline \multicolumn{8}{|c|}{2017} \\
\hline Sahryń & Rapeseed & 4.00 & Panorama KWS & $\begin{array}{l}\mathrm{N}-160 \text { (variant No } 0 \text { ) and } 112 \text { (variants No } 1 \text { and } \\
\text { No 2); } \mathrm{P}-45.8 ; \mathrm{K}-237 ; \mathrm{S}-8.4\end{array}$ & 31st of March & 12th of October & 196 \\
\hline Pagów & $\begin{array}{l}\text { Winter } \\
\text { wheat }\end{array}$ & 7.00 & Artus & $\begin{array}{l}\text { N-156 (variant No 0) and } 109 \text { (variants No } 1 \text { and } \\
\text { No 2); P-39.7; K-302; S-13.0; Ca-61.5; } \mathrm{Mg}-37.2 \text {; } \\
\text { Na-25.9 }\end{array}$ & 31st of March & $\begin{array}{l}\text { 17th of } \\
\text { November }\end{array}$ & 200 \\
\hline Stegienka & $\begin{array}{l}\text { Winter } \\
\text { wheat }\end{array}$ & 6.00 & Piast & $\begin{array}{c}\mathrm{N}-119 \text { (variant } \mathrm{No} 0 \text { ) and } 83 \text { (variants } \mathrm{No} 1 \text { and No } \\
\text { 2); } \mathrm{P}-13.1 ; \mathrm{K}-183 ; \mathrm{S}-13.0 ; \mathrm{Ca}-14.3 ; \mathrm{Mg}-3.6 \text {; } \\
\mathrm{Na}-3.0\end{array}$ & 7th of April & $\begin{array}{l}\text { 15th of } \\
\text { September }\end{array}$ & 130 \\
\hline \multicolumn{8}{|c|}{2018} \\
\hline Sahryń & $\begin{array}{l}\text { Winter } \\
\text { rapeseed }\end{array}$ & 6.90 & Levanda KWS & $\begin{array}{l}\mathrm{N}-175 \text { (variant No } 0 \text { ) and } 123 \text { (variants } \mathrm{No} 1 \text { and } \\
\text { No 2); } \mathrm{P}-34.9 ; \mathrm{K}-249 ; \mathrm{S}-11.2 ; \mathrm{Ca}-13.6 ; \mathrm{Mg}-13.3\end{array}$ & 11th of April & 7th of September & 147 \\
\hline \multicolumn{8}{|c|}{2019} \\
\hline Sahryń & $\begin{array}{l}\text { Winter } \\
\text { rapeseed }\end{array}$ & 3.10 & Toleranza KWS & $\begin{array}{l}\mathrm{N}-159 \text { (variant } \mathrm{No} 0 \text { ) and } 111 \text { (variants } \mathrm{No} 1 \text { and } \\
\text { No 2); } \mathrm{P}-34.9 ; \mathrm{K}-249 ; \mathrm{S}-11.2 ; \mathrm{Ca}-7.2 ; \mathrm{Mg}-12\end{array}$ & 30th of March & $\begin{array}{l}\text { 26th of } \\
\text { September }\end{array}$ & 179 \\
\hline Pagów & $\begin{array}{l}\text { Winter } \\
\text { wheat }\end{array}$ & 5.55 & Tapir & $\begin{array}{l}\mathrm{N}-140 \text { (variant No } 0 \text { ) and } 98 \text { (variants } \mathrm{No} 1 \text { and No } \\
\text { 2); } \mathrm{P}-18.3 ; \mathrm{K}-173 ; \mathrm{S}-44.8 ; \mathrm{Mg}-29.3 ; \mathrm{Na}-15.1\end{array}$ & 23rd of March & $\begin{array}{l}\text { 12th of } \\
\text { November }\end{array}$ & 203 \\
\hline Keppina & $\begin{array}{l}\text { Winter } \\
\text { wheat }\end{array}$ & 5.50 & Levanda KWS & $\begin{array}{l}\mathrm{N}-112 \text { (variant } \mathrm{No} 0 \text { ) and } 78 \text { (variants } \mathrm{No} 1 \text { and } \mathrm{No} \\
\text { 2); } \mathrm{P}-15.7 ; \mathrm{K}-174 ; \mathrm{S}-23 ; \mathrm{Ca}-43 ; \mathrm{Mg}-23 ; \mathrm{Na}-4.5\end{array}$ & 5th of April & $\begin{array}{l}15 \text { th of } \\
\text { September }\end{array}$ & 162 \\
\hline
\end{tabular}

0-Control; 1-Penergetic $(\mathrm{K}+\mathrm{P})$; and 2-Penergetic $(\mathrm{K}+\mathrm{P})+$ Azoter. 
Penergetic-K and Penergetic-P are growth activators, the compositions of which are reserved by the manufacturer. They are produced based on bentonite and molasses processed by a special technology. The product contains no other chemical substances. The Penergetic International AG Company produces Penergetic-P and $-\mathrm{K}$, from bentonite clays subjected to the application of electric and magnetic fields. These products are used to increase the photosynthetic efficiency of plants (Penergetic-P) or to improve the performance of organic matter decomposing organisms of the soil (Penergetic-K).

Azoter is a preparation that contains plant growth-promoting rhizobacteria (PGPR). The total number of living microorganisms (Azotobacter chroococcum, Azospirillum brasilense, and Bacillus megaterium) is at least $4 \times 10^{9} \mathrm{KTJ} \mathrm{cm}^{-3}$, $\mathrm{pH}=5.8-8.5$.

The number of replications was 4 , and the total number of plots was 12. Each plot consisted of six rows. The dimensions of a single plot were a length of $16 \mathrm{~m}$ and width of $2.7 \mathrm{~m}\left(43.2 \mathrm{~m}^{2}\right)$, of which $21.6 \mathrm{~m}^{2}$ (three middle rows) was used for harvesting. During harvest, the plants were topped by hand on the three middle rows, and the leaves were weighed. The roots were then counted, dug up, and weighed. During the harvest, each plot was collected in accordance with the Polish Standard [39]. The root samples were transported to the Plant Breeding Station of the Kutno Sugar Beet Breeding Company in Śmiłów, where they were processed into pulp. The pulp was transported to Straszków, where the technological quality of the roots was evaluated on the automatic Venema technological line [40]: the sugar content polarimetrically [41], the K and Na by photoelectric flame photometry [41], and the $\alpha$-amino nitrogen by fluorometric methods [42].

The measurements performed in the experiments were as follows:

- Plant density at harvest (thousand plants $\mathrm{ha}^{-1}$ );

- $\quad$ Root yield $\left(\mathrm{t} \mathrm{ha}^{-1}\right)$;

- Yield of leaves $\left(t \mathrm{tha}^{-1}\right)$;

- Yield of fresh biomass $\left(\mathrm{t} \mathrm{ha}^{-1}\right)$ as a sum of the root yield $\left(\mathrm{t} \mathrm{ha}^{-1}\right)$ and yield of leaves $\left(\mathrm{t} \mathrm{ha} \mathrm{h}^{-1}\right)$;

- Harvest index (HI) as a ratio of root yield to fresh biomass;

- Foliage coefficient as a ratio of yield of leaves to root yield;

- Fresh biomass of root $(\mathrm{kg})$ as a ratio of root yield $(\mathrm{kg})$ and number of plants per plot at harvest;

- Fresh biomass of leaves per plant $(\mathrm{kg})$ as a ratio of $(\mathrm{kg})$ and number of plants per plot at harvest;

- Plant fresh weight $(\mathrm{kg})$ as the sum of fresh root mass $(\mathrm{kg})$ and leaves of a single plant $(\mathrm{kg})$;

- Content of sucrose in roots (\%);

- Content of $\alpha$-amino nitrogen in the roots $\left(\mathrm{mmol} \mathrm{kg}^{-1}\right)$;

- Content of potassium $(\mathrm{K})$ in the roots $\left(\mathrm{mmol} \mathrm{kg}^{-1}\right)$;

- Content of sodium $(\mathrm{Na})$ in the roots $\left(\mathrm{mmol} \mathrm{kg}^{-1}\right)$;

- Biological yield of sugar $\left(\mathrm{t} \mathrm{ha}^{-1}\right)=$ product of root yield $\left(\mathrm{t} \mathrm{ha} \mathrm{H}^{-1}\right)$ and content of sugar in roots $(\%)$;

- Pure sugar yield $\left(\mathrm{t} \mathrm{ha}^{-1}\right)=$ root yield $\left(\mathrm{t} \mathrm{ha}^{-1}\right) \times$ [content of sugar $(\%)-$ sugar yield losses $\left.(\%)\right]$ [43];

- $\quad$ Sugar yield losses $(\%)=$ standard molasses losses $(\%)+0.6(\%)$;

- Standard molasses losses $(\%)=0.012 \times(\mathrm{K}+\mathrm{Na})+0.024(\alpha$-amino nitrogen $)+0.48$; where the content of $\mathrm{K}, \mathrm{Na}$ and $\alpha$-amino nitrogen are given in $\mathrm{mmol} \mathrm{kg}{ }^{-1}$ of pulp;

- $\quad$ Refined sugar content $(\%)$ = sucrose content $(\%)$ - sugar yield losses $(\%)$;

- $\quad$ Sugar productivity $(\%)=$ refined sugar content $(\%)$ /sugar content $(\%) \times 100$;

- Alkalinity coefficient $\mathrm{W}_{\mathrm{A}}=\left(\right.$ content of $\mathrm{K}\left(\mathrm{mmol} \mathrm{kg}^{-1}\right)+$ content of $\left.\mathrm{Na}\left(\mathrm{mmol} \mathrm{kg}^{-1}\right)\right) /$ content of $\alpha$-amino nitrogen $\left(\mathrm{mmol} \mathrm{kg}^{-1}\right)$ [44].

The data were analyzed using analysis of variance and multiple comparison of means using Tukey's procedure. The significance level for all the analyses was set at 0.05 . The analyses were performed using Statistica 13 software (TIBCO Software Inc., Palo Alto, CA, USA). Descriptive statistics, such as the minimum, maximum, standard deviation (SD), and coefficient of variation (CV) were calculated. 


\section{Results}

In certain locations, we observed that combinations No 1 and 2 were characterized by a higher content of nitrate nitrogen $\left(\mathrm{N}-\mathrm{NO}_{3}\right)$ and ammonium nitrogen $\left(\mathrm{N}-\mathrm{NH}_{4}\right)$ and, consequently, higher amounts of mineral nitrogen ( $\mathrm{Nmin}$ ) and higher contents of $\mathrm{P}, \mathrm{K}$, and $\mathrm{Mg}$ in the soil in comparison to the control treatment, 0 (Table 4).

Table 4. Soil conditions after the harvest of sugar beet (2017-2019).

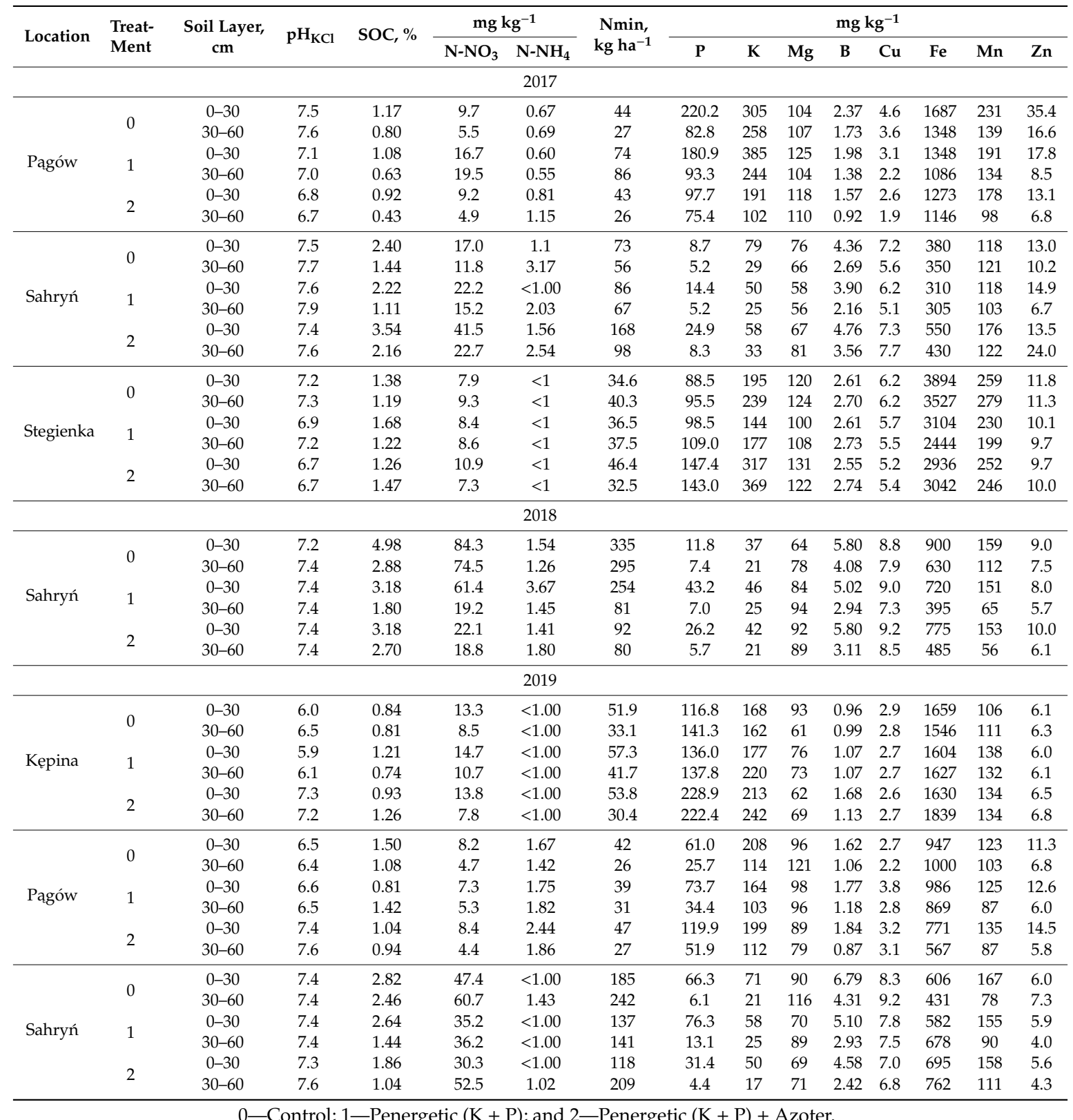

Variant No 1 (by 5.5\%) and variant No 2 (by 5.1\%) had significantly greater plant density during harvest in relation to the control object (Table 5). 
Table 5. The influence of Penergetic activators (Penergetic International AG, Romanshorn, Switzerland) and Azoter bacterial preparation (Azoter Trading, Bratislava, Slovakia) on the yield, the technological quality of the roots and traits of sugar beet plants (2017-2019), and the effects of treatment, environment (location $\times$ year), and their interaction.

\begin{tabular}{|c|c|c|c|c|c|c|}
\hline \multirow[b]{2}{*}{ Trait } & \multicolumn{3}{|c|}{ Treatment } & \multicolumn{3}{|c|}{$p$-Value Based on ANOVA } \\
\hline & 0 & 1 & 2 & Treatment $(\mathrm{T})$ & $\begin{array}{l}\text { Environment } \\
\text { (E: Year } \times \\
\text { Location) }\end{array}$ & $\begin{array}{c}\text { Inter-Action: } \\
\qquad \mathrm{T} \times \mathrm{E}\end{array}$ \\
\hline $\begin{array}{l}\text { Plant density at harvest, } \\
\text { thousand plants } \mathrm{ha}^{-1}\end{array}$ & $90.16 a^{*}$ & $95.10 \mathrm{~b}$ & $94.71 \mathrm{~b}$ & 0.054 & $<0.001$ & 0.735 \\
\hline Yield of leaves, $\mathrm{t} \mathrm{ha}^{-1}$ & $49.95 \mathrm{a}$ & $47.75 \mathrm{a}$ & $53.99 \mathrm{~b}$ & 0.002 & $<0.001$ & $<0.001$ \\
\hline Yield of roots, $\mathrm{tha}^{-1}$ & $84.46 \mathrm{a}$ & $90.65 \mathrm{~b}$ & $94.17 \mathrm{~b}$ & $<0.001$ & $<0.001$ & 0.051 \\
\hline Yield of roots and leaves, $\mathrm{tha}^{-1}$ & $134.41 \mathrm{a}$ & $138.40 \mathrm{a}$ & $148.16 \mathrm{~b}$ & $<0.001$ & $<0.001$ & 0.002 \\
\hline Biological yield of sugar, $\mathrm{t} \mathrm{ha}^{-1}$ & $14.20 \mathrm{a}$ & $15.05 \mathrm{~b}$ & $16.00 \mathrm{c}$ & $<0.001$ & $<0.001$ & 0.003 \\
\hline Pure sugar yield, $\mathrm{tha}^{-1}$ & $12.41 \mathrm{a}$ & $13.19 \mathrm{~b}$ & $14.07 \mathrm{c}$ & $<0.001$ & $<0.001$ & 0.002 \\
\hline Harvest Index & $0.64 \mathrm{a}$ & $0.66 \mathrm{~b}$ & $0.65 \mathrm{ab}$ & 0.052 & $<0.001$ & $<0.001$ \\
\hline Foliage coefficient & $0.60 \mathrm{~b}$ & $0.54 \mathrm{a}$ & $0.58 \mathrm{ab}$ & 0.027 & $<0.001$ & $<0.001$ \\
\hline Content of sucrose in roots, $\%$ & $16.80 \mathrm{ab}$ & $16.63 \mathrm{a}$ & $16.96 \mathrm{~b}$ & 0.109 & $<0.001$ & 0.001 \\
\hline $\begin{array}{l}\text { The content of } \alpha \text {-amino nitrogen } \\
\text { in the roots, } \mathrm{mmol} \mathrm{kg}^{-1}\end{array}$ & $21.36 \mathrm{a}$ & $21.11 \mathrm{a}$ & 20.89 a & 0.894 & $<0.001$ & 0.176 \\
\hline $\begin{array}{l}\text { Potassium content in the roots, } \\
\qquad \mathrm{mmol} \mathrm{kg}^{-1}\end{array}$ & $39.84 \mathrm{~b}$ & $35.15 \mathrm{a}$ & $36.09 \mathrm{a}$ & $<0.001$ & $<0.001$ & 0.002 \\
\hline $\begin{array}{l}\text { Sodium content in the roots, } \\
\text { mmol kg-1 }\end{array}$ & $3.53 \mathrm{~b}$ & $3.22 \mathrm{ab}$ & $2.90 \mathrm{a}$ & 0.125 & $<0.001$ & 0.019 \\
\hline Standard molasses losses, $\%$ & $1.51 \mathrm{~b}$ & $1.45 \mathrm{a}$ & $1.45 \mathrm{a}$ & 0.052 & $<0.001$ & 0.396 \\
\hline Sugar yield losses, \% & $2.11 \mathrm{~b}$ & $2.05 \mathrm{a}$ & $2.05 \mathrm{a}$ & 0.052 & $<0.001$ & 0.396 \\
\hline Refined sugar content, \% & $14.69 \mathrm{ab}$ & $14.58 \mathrm{a}$ & $14.91 \mathrm{~b}$ & 0.106 & $<0.001$ & 0.001 \\
\hline Sugar productivity, \% & $87.29 \mathrm{a}$ & $87.57 \mathrm{ab}$ & $87.75 \mathrm{~b}$ & 0.121 & $<0.001$ & 0.188 \\
\hline Alkalinity coefficient & $2.24 \mathrm{~b}$ & $1.91 \mathrm{a}$ & $1.96 \mathrm{a}$ & 0.001 & $<0.001$ & $<0.001$ \\
\hline $\begin{array}{c}\text { The fresh mass of the leaves of } \\
\text { the plant, } \mathrm{kg}\end{array}$ & $0.55 b^{*}$ & $0.51 \mathrm{a}$ & $0.57 \mathrm{~b}$ & 0.014 & $<0.001$ & $<0.001$ \\
\hline Fresh root mass, $\mathrm{kg}$ & $0.94 \mathrm{a}$ & $0.96 \mathrm{a}$ & $1.00 \mathrm{a}$ & 0.136 & $<0.001$ & 0.002 \\
\hline Fresh plant biomass, $\mathrm{kg}$ & $1.49 \mathrm{ab}$ & $1.47 \mathrm{a}$ & $1.57 \mathrm{~b}$ & 0.038 & $<0.001$ & 0.002 \\
\hline
\end{tabular}

* The same letters within rows indicate a lack of significant differences between means at $\alpha=0.05$.

The use of Penergetic activators (variant No 1) resulted in a significant increase in the root yield (by $7.3 \%$ ), harvest index value (by 3.1\%), biological sugar yield (by 6.0\%), and pure sugar yield (by 6.3\%) and a significant reduction in the potassium content in the roots (by 11.8\%), the foliage coefficient (by $10.0 \%$ ), the standard molasses losses (by $4.0 \%$ ), the sugar yield losses (by $2.8 \%$ ), and the value of the alkalinity coefficient (by 14.7\%) compared to the control object (Table 5, Figure 2).

Combination No 2 demonstrated a significant increase in the yield of leaves (by $8.1 \%$ ), the yield of roots (by 11.5\%), the total yield of roots and leaves (by 10.2\%), the biological yield of sugar (by 12.7\%), the pure sugar yield (by 13.4\%), and the sugar productivity (by $0.5 \%$ ) and a significant reduction in the potassium (by 9.4\%) and sodium (by 17.9\%) content in roots, the standard molasses losses (by $4.0 \%$ ), the sugar yield losses (by 2.8\%), and the value of the alkalinity coefficient (by $12.5 \%$ ) in relation to the control combination.

The Penergetic + Azoter facility was characterized by a significantly higher yield of leaves (by $13.1 \%$ ), sugar content in the roots (by $2.0 \%$ ), total yield of roots and leaves (by 7.1\%), fresh mass of the plant leaves (by $11.8 \%$ ), fresh mass of the plant (by $6.3 \%$ ), biological yield of sugar (by $6.3 \%$ ), pure sugar yield (by $6.7 \%$ ), and content of the refined sugar (by $2.3 \%$ ) compared to the Penergetic object.

For the majority of the studied traits, a significant effect of the environment (years $\times$ location) was observed as well as a significant interaction between the treatments and environments, which indicates that the effect of the combinations varied in different years and locations.

Among the examined traits, the highest variability was found in the sodium content in the roots $(\mathrm{CV}=49.3 \%)$, and the lowest variability was found in the sugar productivity $(\mathrm{CV}=2.3 \%)$ (Table 6$)$. 


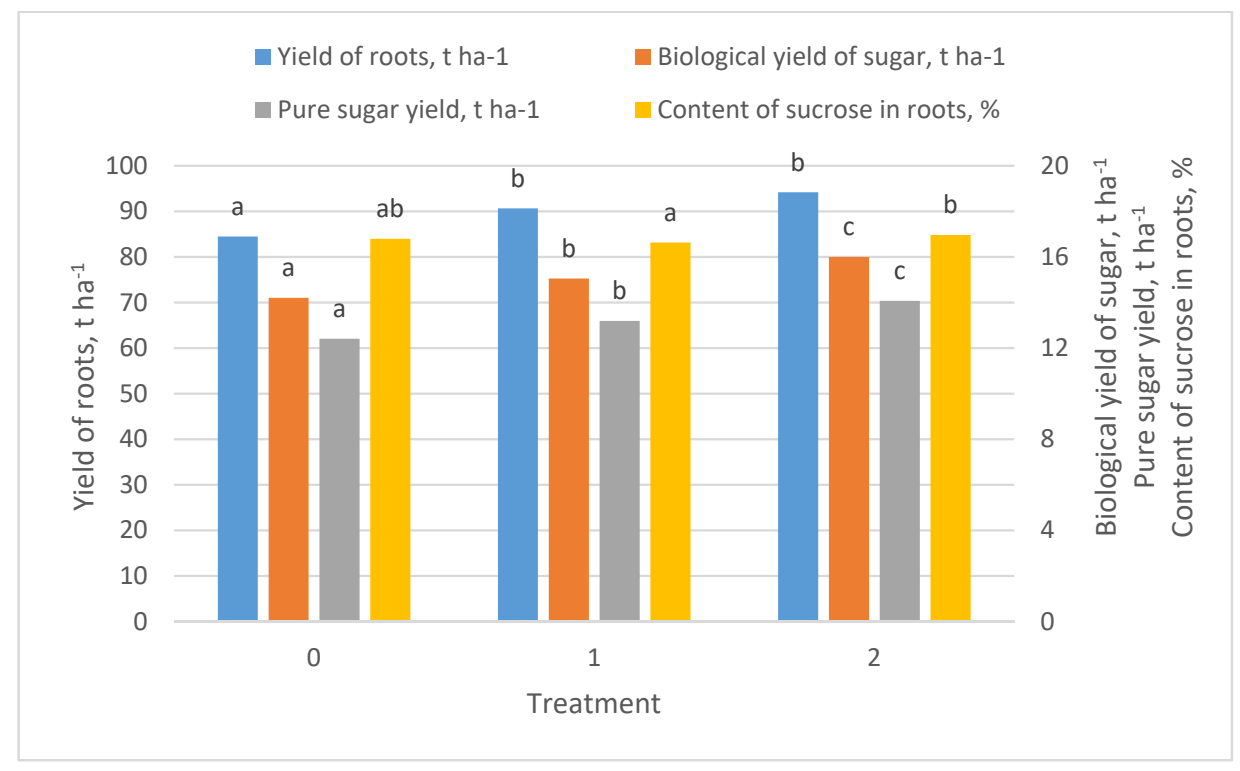

Figure 2. The influence of Penergetic activators and Azoter bacterial preparation on the yield of roots, sugar yield, and sucrose content (2017-2019). (The same letters under the columns in the same color indicate a lack of significant differences between means at $\alpha=0.05$ ).

Table 6. Descriptive statistics for all experiments with sugar beet (2017-2019).

\begin{tabular}{|c|c|c|c|c|c|}
\hline Trait & Mean & Minimum & Maximum & $\begin{array}{c}\text { Standard } \\
\text { Deviation (SD) }\end{array}$ & $\begin{array}{c}\text { Coefficient of } \\
\text { Variation (CV), \% }\end{array}$ \\
\hline $\begin{array}{l}\text { Plant density at harvest, thousand } \\
\text { plants ha }{ }^{-1}\end{array}$ & 93.32 & 65.00 & 112.04 & 11.89 & 12.74 \\
\hline Yield of leaves, $\mathrm{tha}^{-1}$ & 50.56 & 21.60 & 106.48 & 21.91 & 43.34 \\
\hline Yield of roots, $t_{\text {ha }}{ }^{-1}$ & 89.76 & 61.11 & 117.66 & 15.38 & 17.14 \\
\hline Yield of roots and leaves, $\mathrm{tha}^{-1}$ & 140.3 & 93.06 & 204.63 & 28.51 & 20.31 \\
\hline Biological yield of sugar, $\mathrm{tha}^{-1}$ & 15.08 & 9.87 & 21.14 & 2.98 & 19.76 \\
\hline Pure sugar yield, $\mathrm{tha}^{-1}$ & 13.23 & 8.32 & 18.96 & 2.75 & 20.79 \\
\hline Harvest Index & 0.65 & 0.45 & 0.81 & 0.09 & 13.81 \\
\hline Foliage coefficient & 0.57 & 0.24 & 1.24 & 0.25 & 43.44 \\
\hline Content of sucrose in roots, $\%$ & 16.80 & 14.45 & 20.29 & 1.55 & 9.22 \\
\hline $\begin{array}{l}\text { The content of } \alpha \text {-amino nitrogen } \\
\text { in the roots, } \mathrm{mmol} \mathrm{kg}^{-1}\end{array}$ & 21.12 & 11.00 & 44.10 & 6.86 & 32.46 \\
\hline $\begin{array}{l}\text { Potassium content in the roots, } \\
\qquad \mathrm{mmol} \mathrm{kg}^{-1}\end{array}$ & 37.03 & 27.00 & 55.00 & 6.63 & 17.90 \\
\hline $\begin{array}{l}\text { Sodium content in the roots, } \\
\qquad \mathrm{mmol} \mathrm{kg}^{-1}\end{array}$ & 3.22 & 1.15 & 13.40 & 1.59 & 49.29 \\
\hline Standard molasses losses, $\%$ & 1.47 & 1.16 & 2.20 & 0.22 & 15.23 \\
\hline Sugar yield losses, \% & 2.07 & 1.76 & 2.80 & 0.22 & 10.82 \\
\hline Refined sugar content, $\%$ & 14.73 & 12.31 & 18.28 & 1.64 & 11.15 \\
\hline Sugar productivity, $\%$ & 87.53 & 81.45 & 90.30 & 2.03 & 2.32 \\
\hline Alkalinity coefficient & 2.04 & 1.05 & 4.14 & 0.55 & 27.19 \\
\hline $\begin{array}{l}\text { The fresh mass of the leaves of the } \\
\text { plant, } \mathrm{kg}\end{array}$ & 0.54 & 0.22 & 1.10 & 0.22 & 40.14 \\
\hline Fresh root mass, $\mathrm{kg}$ & 0.97 & 0.56 & 1.42 & 0.14 & 14.49 \\
\hline Fresh plant biomass, $\mathrm{kg}$ & 1.51 & 0.85 & 2.11 & 0.26 & 17.24 \\
\hline
\end{tabular}

\section{Discussion}

We obtained, in our study, the increase in the amount of mineral nitrogen in the soil after sugar beet harvesting in combinations with Penergetic activators. This confirmed the results of previous studies in which the use of the Penergetic-K $\left(300 \mathrm{~g} \mathrm{ha}^{-1}\right)$ activator in pre-sowing spraying in organic winter wheat cultivation resulted in an increase in $\mathrm{pH}$, redox potential, and specific soil electric conductivity [14]. The process of mineralization increased when the oxidation was stronger, and this 
caused an increase in the amount of mineral nitrogen in the soil after the crop harvest. The combined use of Penergetic with phosphorus and potassium mineral fertilization promoted the activity of fauna and microorganisms present in the $0-8 \mathrm{~cm}$ soil layer in soybeans. The activity of fauna and microorganisms in the 9-16 cm soil layer was intensified with the use of Penergetic, alone or with phosphate and potassium fertilization, in soybeans. The use of Penergetic did not significantly increase the soil biological activity in the winter crop [45].

The use of the activators Penergetic-K and Penergetic-P combined with a reduced dose of mineral nitrogen (reduced by $30 \%$ ), increased the yield of the roots by $7.3 \%$, the fresh root mass by $2.1 \%$, the biological yield of sugar by $6.0 \%$, and the pure sugar yield by $6.3 \%$ and reduced the sugar content of the roots by 0.17 p.p. in comparison with the control treatment (without the Penergetic activators and with a full dose of mineral nitrogen). In the literature, there are few results of experiments with the use of Penergetic activators in the cultivation of sugar beet. In one, foliar spray of Penergetic-P $\left(0.1 \mathrm{dm}^{3} \mathrm{ha}^{-1}\right)$ applied in the growth stage of BBCH 18-19 of sugar beet caused an increase in the before-harvest content of chlorophyll $a$ (by $5.6 \%$ ), chlorophyll $b$ (by $8.6 \%$ ), chlorophyll $a+b$ (by $6.4 \%$ ), and carotenoids (by 3.0\%) in comparison to the control [11]. Root yield increased by $14.5 \%$, and the average root mass increased by $9.1 \%$. However, the sucrose content in the roots increased by 0.34 p.p., and the yield of white sugar increased by $17.2 \%$.

The results of experiments with the use of Penergetic activators in the cultivation of crops other than sugar beet are available in the literature. The application of Penergetic-P in potato cultivation increased the share of large tubers from $39 \%$ to $55.9 \%$ and reduced the proportion of small tubers from $32.0 \%$ to $19.3 \%$ and, consequently, increased the yield of tubers by $16.6 \%$ in comparison to the control [10]. The application of Penergetic before sowing (dose $300 \mathrm{~g} \mathrm{ha}^{-1}$ ) in organic winter wheat caused an increase in grain yield by $5.0 \%$ in comparison to the control and an improvement of grain quality (increase in the protein content by $2.4 \%$ and gluten by $2.9 \%$ ) [14].

Penergetic in soybeans did not affect the plant growth. However, the grain weight per plant and yield of soybeans were higher (by $20 \%$ ) in comparison with the application of the fertilizer NPK and micronutrients [15].

Soil and foliar application of Penergetic-P in spring wheat caused an increase in the grain yield in comparison to wheat grown without such application. Penergetic-P applied to the soil and by foliar application resulted in a substantial increase in the number of seeds per spike, and lengthening of the stems compared with wheat in the control treatment [46].

In a greenhouse experiment performed in Brazil in green beans, the dry matter yield of commercial pods was not significantly different between objects with Penergetic-P and Penergetic-K and full mineral fertilization (NPK) versus objects with Penergetic-P and Penergetic-K with a $25 \%$ dose of NPK [12]. Penergetic-P positively influenced the germination of radish and tomato seeds as well as the growth and development of cucumber, red beet, tomato, and radish seedlings [16]. The use of Penergetic-P on the sowing day for winter wheat seeds in organic cultivation had a positive effect on the health of seeds and the root system assessed at the beginning of autumn during tilling (BBCH 21-23). Infestation of cocci by Fusarium spp. was reduced from $13.5 \%$ in the control to $9.0 \%$, and root diseases were reduced from $71.7 \%$ to $55.0 \%$ [17].

There are also experimental results proving the beneficial effect of the Penergetic growth activators on the nutrition and yield of coffee, and the effect was dependent on the cover plants on the plantation [13]. Nascente and Cobucci [18] evaluated the effect of the application of Penergetic-K and Penergetic-P on the yield of common beans with diversified fertilization with phosphorus. A greater availability of $\mathrm{P}$ to plants when Penergetic was applied was possibly due to the soil colloids and organics or partly due to the increased microbial activity in the soil.

There are no results from studies with the use of Penergetic activators together with plant growth-promoting rhizobacteria. In our own research, we observed that the use of Penergetic activators together with the Azoter activator containing bacteria Azotobacter chroococcum, Azospirillum brasilense, and Bacillus megaterium caused an increase in the yield of roots by $3.9 \%$, the fresh root mass by $4.2 \%$, 
biological yield of sugar by $6.3 \%$, pure sugar yield by $6.7 \%$, and sugar content in the roots by 0.33 p.p. in comparison to the object with only Penergetic activators.

Inoculation by Azospirillum sp. of dryland crops showed a grain yield increase on winter (by $14.0 \%$ ) and spring cereals (by 9.5\%) and also on legumes (by 6.6\%). Inoculation with selected strains of Azospirillum sp. increased crop yields and enhanced the efficacy in plant nutrient availability [23]. The inoculation of maize seeds with Azospirillum brasilense intensified the plant growth, improved biochemical traits, and raised the nitrogen use efficiency under a nitrogen deficit [47]. Little effect of inoculation with Azospirillum brasilense on grain yield was observed for wheat (Triticum aestivum) [48]. A beneficial influence of co-inoculation of Azospirillum lipoferum and Baccilus megaterium was observed for providing balanced $\mathrm{N}$ and $\mathrm{P}$ nutrition for wheat plants [49].

The research on Azotobacter chroococcum spp. in crop production has manifested its significance in plant nutrition and its contribution to soil fertility. The Azotobacteria genus synthesizes auxins, cytokinins, and GA-like (Gibberellin-like) substances, and these growth materials are the primary substances controlling enhanced growth. These hormonal substances affect the growth of the closely associated higher plants [50].

\section{Conclusions}

The results obtained in several locations proved that it was possible to reduce the fertilization of sugar beet with mineral nitrogen by $30 \%$ without reducing the biological yield of sugar and pure sugar yield, and even to obtain an increase as a result of the use of the Penergetic-K and Penergetic-P growth activators and the Azoter preparation containing the bacteria Azotobacter chroococcum, Azospirillum brasilense, and Bacillus megaterium. This proved that high sugar yields can be obtained with more environmentally friendly technologies.

Author Contributions: Conceptualization, A.A.; formal analysis, A.A.; investigation, A.A.; methodology, A.A.; supervision, A.A.; visualization, D.G.; writing—original draft, A.A. and D.G.; writing-review and editing, A.A. and D.G. Both authors have read and agreed to the published version of the manuscript.

Funding: This research received no external funding.

Conflicts of Interest: The authors declare no conflict of interest.

\section{References}

1. Weekley, J.; Gabbard, J.; Nowak, J. Micro-level management of agricultural inputs: Emerging approaches. Agronomy 2012, 2, 321-357. [CrossRef]

2. Artyszak, A. Possibilities of Using Silicon for Foliar Fertilization of Sugar Beet; Wieś Jutra: Warsaw, Poland, 2017; p. 128.

3. Artyszak, A. Effect of silicon fertilization on crop yield quantity and quality-A literature review in Europe. Plants 2018, 7, 54. [CrossRef] [PubMed]

4. Artyszak, A.; Gozdowski, D.; Kucińska, K. The effect of foliar fertilization with marine calcite in sugar beet. Plant Soil Environ. 2014, 60, 413-417. [CrossRef]

5. Artyszak, A.; Gozdowski, D.; Kucińska, K. The effect of silicon foliar fertilization in sugar beet-Beta vulgaris (L.) ssp. vulgaris conv. crassa (Alef.) prov. altissima (Döll). Turk. J. Field Crop. 2015, 20, 115-119. [CrossRef]

6. Artyszak, A.; Gozdowski, D.; Kucińska, K. The effect of calcium and silicon foliar fertilization in sugar beet. Sugar Tech 2016, 18, 109-114. [CrossRef]

7. Artyszak, A.; Kucińska, K. Silicon nutrition and crop improvement: Recent advances and future perspective. In Silicon in Plants; Tripathi, D.K., Singh, V.P., Ahmad, P., Chauhan, D.K., Prasad, S.M., Eds.; CRC Press Taylor \& Francis Group Boca Raton: London, UK; New York, NY, USA, 2016; pp. 297-319.

8. Hřivna, L.; Hernandez Kong, J.; Machálková, L.; Burešová, I.; Sapáková, E.; Kučerová, J.; Šottníková, V. Vliv mimokořenové výživy draslíkem a křemíkem na výnos a kvalitu cukrovky v nestandardních povětrnostních podmínkách roku 2014 and 2015. Listy Cukrov. Repar. 2017, 133, 182-187.

9. Urban, J.; Pulkrabek, J. Navyšeni vynosu a jakosti cukrove řepy pomoci listove vyživy a biologicky aktivnich. Listy Cukrov. Repar. 2018, 134, 188-194. 
10. Jakiene, E.; Venskutonis, V.; Mickevicius, V. The effect of additional fertilization with liquid complex fertilizers and growth regulators on potato productivity. Sodininkyste Daržininkyste் 2008, 27, 259-267.

11. Jakiene, E.; Venskutonis, V.; Liakas, V. Fertilization of sugar beet root with ecological fertilizers. Agron. Res. 2009, 7, 269-276.

12. Brito, O.R.; Dequech, F.K.; Brito, R.M. Use of Penergetic products $\mathrm{P}$ and $\mathrm{K}$ in the snap bean production. Annu. Rep. 2012, 55, 279-280.

13. Franco, K.S., Jr.; Terra, A.B.C.; Teruel, T.R.; Mantovani, J.R.; Florentino, L.A. Effect of cover crops and bioactivators in coffee and chemical properties of soil. Coffee Sci. Lavras 2018, 13, 559-567.

14. Pekarskas, J.; Vilkenyte, L.; Sileikiene, D.; Cesoniene, L.; Makarenko, N. Effect of organic nitrogen fertilizers Provita and fermentator Penergetic-K winter Wheat and on soil quality. In Proceedings of the 8th International Conference, Environmental Engineering, Vilnius, Lithuania, 19-20 May 2011; pp. 248-254.

15. De Souza, A.A.; de Almeida, F.Z.; Alberton, O. Growth and yield of soybean with Penergetic application. Sci. Agrar. 2017, 18, 95-98.

16. Jankauskienè, J.; Survilienè, E. Influence of growth regulators on seed germination energy and biometrical parameters of vegetables. Sodininkystė Daržininkystė 2009, 28, 69-77.

17. Kadziuliene, Z.; Feiziene, D.; Leistrumaite, A.; Semaskiene, R. Peculiarities of some legumes and cereals under organic farming system. NJF-Seminar 369. Organic farming for a new millennium-Status and future challenges. Published by Nordic Association of Agricultural Scientists (NJF), Section I: Soil, Water and Environment Swedish University of Agricultural Sciences Alnarp, Sweden June 15-17 2005. NJF Rep. 2005, 1, 103-106.

18. Nascente, A.S.; Cobucci, T. Phosphate fertilization in the soil and Penergetic application in the grain yield of common bean. Soils Embrace Life and Universe. In Proceedings of the 20th World Congress of Soil Science, Jeju, Korea, 8-13 June 2014.

19. Khalid, A.; Arshad, M.; Shaharoona, B.; Mahmood, T. Plant growth promoting Rhizobacteria and sustainable agriculture. In Microbial Strategies for Crop Improvement; Khan, M., Zaidi, A., Musarrat, J., Eds.; Springer: Berlin/Heidelberg, Germany, 2009; pp. 133-160.

20. Egamberdieva, D.; Shrivastava, S.; Varma, A. Plant Growth Promoting Rhizobacteria (PGPR) and Medicinal Plants; Springer: Berlin/Heidelberg, Germany; New York, NY, USA; Dordrecht, The Netherlands; London, UK, 2015.

21. Yadav, G.; Vishwakarma, K.; Sharma, S.; Kumar, V.; Upadhyay, N.; Kumar, N.; Verma, R.K.; Mishra, R.; Tripathi, D.K.; Upadhyay, R.G. Emerging Significance of Rhizospheric Probiotics and Its Impact on Plant Health: Current Perspective Towards Sustainable Agriculture. In Probiotics and Plant Health; Kumar, V., Kumar, M., Sharma, S., Prasad, R., Eds.; Springer Nature Singapore Pte Ltd.: Singapore, 2017; pp. 233-251.

22. García-Fraile, P.; Menéndez, E.; Celador-Lera, L.; Díez-Méndez, A.; Jiménez-Gómez, A.; Marcos-García, M.; Cruz-González, X.A.; Martínez-Hidalgo, P.; Mateos, P.F.; Rivas, R. Bacterial probiotics: A truly green revolution. In Probiotics and Plant Health; Kumar, V., Kumar, M., Sharma, S., Prasad, R., Eds.; Springer Nature Singapore Pte Ltd.: Singapore, 2017; pp. 131-162.

23. Cassán, F.; Diaz-Zorita, M. Azospirillum sp. in current agriculture: From the laboratory to the field. Soil Biol. Biochem. 2016, 103, 117-130. [CrossRef]

24. Glick, B.R. Plant Growth-Promoting Bacteria: Mechanisms and Applications. Scientifica 2012. [CrossRef]

25. Mishra, J.; Singh, R.; Arora, N.K. Plant growth-promoting microbes: Diverse roles in agriculture and environmental sustainability. In Probiotics and Plant Health; Kumar, V., Kumar, M., Sharma, S., Prasad, R., Eds.; Springer Nature Singapore Pte Ltd.: Singapore, 2017; pp. 71-111.

26. Gosal, S.K.; Kaur, J.; Kaur, J. Plant growth-promoting Rhizobacteria: A probiotic for plant health and productivity. In Probiotics and Plant Health; Kumar, V., Kumar, M., Sharma, S., Prasad, R., Eds.; Springer Nature Singapore Pte Ltd.: Singapore, 2017; pp. 589-600.

27. IUSS Working Group WRB. World Reference Base for Soil Resources 2014. International Soil Classification System for Naming Soils and Creating Legends for Soil Maps; Update 2015; World Soil Resources Report 106; FAO: Rome, Italy, 2015.

28. PKN. PN-ISO 10390:1997. Soil Quality—pH Determination; Polish Committee for Standardization: Warsaw, Poland, 1997.

29. Research Procedure of the Regional Agrochemical Station in Warsaw; No. PB 01 ed.; Regional Agrochemical Station: Warsaw, Poland, 2009. 
30. Research Procedure of the Regional Agrochemical Station in Warsaw; No. PB 46 ed.; Regional Agrochemical Station: Warsaw, Poland, 2017.

31. PKN. Polish Standard PN-R-04023:1996. Agro-Chemical Analysis of Soil-Determination of Available Phosphorus Content in Mineral Soils; Polish Committee for Standardization: Warsaw, Poland, 1996.

32. PKN. Polish Standard PN-R-04022:1996/Az1:2002. Agro-Chemical Analysis of Soil-Determination of Available Potassium Content in Mineral Soils; Polish Committee for Standardization: Warsaw, Poland, 1996.

33. PKN. Polish Standard PN-R-04020:1994/Az1:2004. Agro-Chemical Analysis of Soil-Determination of Available Magnesium Content in Mineral Soils; Polish Committee for Standardization: Warsaw, Poland, 1994.

34. PKN. Polish Standard PN-93/R-04018. Agro-Chemical Analysis of Soil. Determination of Available Boron; Polish Committee for Standardization: Warsaw, Poland, 1993.

35. PKN. Polish Standard PN-92/R-04017. Agro-Chemical Analysis of Soil. Determination of Available Copper; Polish Committee for Standardization: Warsaw, Poland, 1992.

36. PKN. Polish Standard PN-R-04021: 1994. Agro-Chemical Analysis of Soil. Determination of Available Iron; Polish Committee for Standardization: Warsaw, Poland, 1994.

37. PKN. Polish Standard PN-93/R-04019. Agro-Chemical Analysis of Soil. Determination of Available Manganese; Polish Committee for Standardization: Warsaw, Poland, 1993.

38. PKN. Polish Standard PN-92/R-04016. Agro-Chemical Analysis of Soil. Determination of Available Zinc; Polish Committee for Standardization: Warsaw, Poland, 1992.

39. PKN. Polish Standard PN-R-74458. Korzenie Buraka Cukrowego/Sugar Beet Roots; Polish Committee for Standardization: Warsaw, Poland, 1999.

40. Hassan, I.; Mostafa, S. Influence of sugar beet nitrogen content on quality and efficiency of sugar extraction. J. Food Dairy Sci. 2018, 9, 111-116. [CrossRef]

41. ICUMSA. International Commission for Uniform Methods of Sugar Analysis. 1994. Available online: http://www.icumsa.org (accessed on 20 August 2020).

42. Burba, M.; Georgi, B. Die fluorometrische Bestimmung der Aminosaüren in Zuckerrüben und Zuckerfabriksprodukten mit Fluoreszamin und o-Phtalaldehyd. Zuckerindustrie 1976, 26, 322-328.

43. Buchholz, K.; Märländer, B.; Puke, H.; Glattkowski, H.; Thielecke, K. Neubewertung des technischen Wertes von Zuckerrben. Zuckerindustrie 1995, 120, 113-121.

44. Trzebiński, J. Ocena wydajności cukru z korzeni. In Produkcja Buraka Cukrowego; Gutmański, I., Ed.; PWRiL: Poznań, Poland, 1991; pp. 591-597.

45. Steffen, G.P.; Maldaner, J.; de Morais, R.M.; Saldanha, C.W.; Steffen, R.B.; Antoniolli, Z.I.; Jacques, R.J.S. Degradation of residues and food activity in soils with biological activation. Int. J. Curr. Res. 2016, 8, 42784-42789.

46. Pekarskas, J. Effect of growth activator Penergetic-P on organically grown spring wheat. Žemés Ūkiio Mokslai 2012, 19, 151-160.

47. Zeffa, D.M.; Perini, L.J.; Silva, M.B.; de Sousa, N.V.; Scapim, C.A.; de Oliveira, A.L.M.; do Amaral Junior, A.T.; Gonçalves, L.S.A. Azospirillum brasilense promotes increases in growth and nitrogen use efficiency of maize genotypes. PLoS ONE 2019, 14, e0215332. [CrossRef] [PubMed]

48. Kazi, N.; Deaker, R.; Wilson, N.; Muhamamd, K.; Trethowan, R. The response of wheat genotypes to inoculation with Azospirillum brasilense in the field. Field Crop. Res. 2016, 196, 368-378. [CrossRef]

49. El-Komy, H.M.A. Coimmobilization of A. lipoferum and B. megaterium for plant nutrition. Food Technol. Biotechnol. 2005, 43, 19-27.

50. Wani, S.A.; Chand, S.; Tahir, A. Potential use of Azotobacter chroococcum in crop production: An overview. Curr. Agric. Res. J. 2013, 1, 35-38. [CrossRef]

(C) 2020 by the authors. Licensee MDPI, Basel, Switzerland. This article is an open access article distributed under the terms and conditions of the Creative Commons Attribution (CC BY) license (http://creativecommons.org/licenses/by/4.0/). 